\title{
Fission-track dating of volcanics in the northern part of the Taiwan-Luzon Arc: eruption ages and evidence for crustal contamination
}

\author{
Tsanyao F. Yang, ${ }^{*} \dagger$ Jung-li Tien, ${ }^{*}$ Cheng-Hong Chen, ${ }^{*}$ Typhoon Lee* $\ddagger$ \\ and Raymundo S. Punongbayan $\S$
}

*Department of Geology, National Taiwan University, Taipei, Taiwan, ROC; †Department of Marine Chemistry and Geochemistry, Woods Hole Oceanographic Institution, Woods Hole, MA 02543, U.S.A.; $\ddagger$ Institute of Earth Sciences, Academia Sinica, Taipei, Taiwan, ROC; §Philippine Institute of Volcanology and Seismology, Quezon City, Philippines

\begin{abstract}
Igneous rocks from the Coastal Range and offshore islets of eastern Taiwan, Camiguin island and northern Luzon of the Philippines, which collectively constitute the northern part of the Taiwan-Luzon Arc, have been dated by the fission-track technique. The pooled ages range widely from $49.9 \mathrm{Ma}$ to $0.02 \mathrm{Ma}$. Some of the samples produce bimodal or even multiple age distributions in composite probability density plots, indicating the presence of inherited "ages" in the dated zircons. A $\chi^{2}$ test shows that most of the $\chi^{2}$ ages are in good agreement with the youngest peak date Except for one intrusive basement sample and five volcanic samples affected by hydrothermal alteration, most of the $\chi^{2}$ ages can be interpreted as the ages of volcanic eruptions. The inherited ages of the zircon populations present in many samples record thermal activities which occurred prior to the eruption of their host magmas. This suggests that upper level crustal contamination has taken place, thereby introducing some xenocrystic zircons into the magmas erupted. The fission-track ages are always younger than or occasionally equal to the ages obtained by other methods for the samples from the same localities. Of six samples dated by the Ar-Ar stepwise heating method four samples have plateau age close to the FTD ages. Some samples do not contain inherited, partially annealed FTD ages and the corresponding $\mathrm{K}-\mathrm{Ar}$ ages are consistent with the FTD ages. A detailed study of $\mathrm{Rb} / \mathrm{Sr}$ isotopic systematics of phenocryst minerals by Lan C. Y., Shen J. J. S. and Lee T. (1986). A $\mathrm{Rb}-\mathrm{Sr}$ isotopic study of andesites from Lutao, Lanhsu, and Hsiao-Lanhsu, eruption ages and isotopic heterogeneity. Bull. Inst. Earth Sci. 6, 211-226 showed isotopic disequilibrium suggesting retention of unequilibrated older volcanic products. Many of the $\mathrm{K}-\mathrm{Ar}$ dates, which are commonly older than the eruption ages determined by the FTD technique, may reflect inherited argon. Based on results from a combination of dating methods, volcanism in the northern part of the Taiwan-Luzon Arc can be deduced to have been active since $26 \mathrm{Ma}$. The igneous activity in the Taiwan Segment (northern part of North Luzon Arc as exposed in the Coastal Range) ceased at $2.2 \mathrm{Ma}$, because of the arc-continent collision. Further southward, away from the present location of the collision zone, the volcanoes are still active.
\end{abstract}

\section{Introduction}

The northern part of the Taiwan-Luzon Arc, which formed in response to the subduction of the South China Sea plate underneath the West Philippine Sea Plate, is currently colliding with the Eurasian continental plate (Fig. 1). The northern part of the arc has already been accreted onto the continental margin resulting in formation of the Coastal Range in eastern Taiwan, where all volcanic activity has ceased (Lo, 1989; Teng, 1990). At its southern end, the arc has collided with the North Palawan-Mindoro Continental Terrain, while subduction and related magmatism continued in the areas between the collision zones. This special tectonic setting provides an ideal place for the study of magmatic activity in relation to subduction and collision between an arc and a continent.

In this paper we are concerned with the northern collision zone. The eruption ages of the volcanics in this area have been studied in the past by several methods. K-Ar ages of $29.7 \sim 0.14 \mathrm{Ma}$ (Richard et al., 1986a, b; Jacques, 1987; Juang, 1988, Defant et al., 1990; Juang and Chen, 1990), $\mathrm{Rb}-\mathrm{Sr}$ mineral isochron ages of 9.4 0.9 Ma (Lan et al., 1986) and $\mathrm{Ar}-\mathrm{Ar}$ ages of $16.0 \sim 1.1 \mathrm{Ma}$ (Lo et al., 1994) have been obtained. There are some assumptions in using these methods, i.e. no inherent Ar problem, initial isotopically homogenization in samples studied and closed system isotopic evolution after eruption. Lan et al. (1986) and Chen (1989), however, found that some phenocrysts in the samples which they studied were not in isotopic equilibrium with their host rocks. This may explain why $\mathrm{Rb}-\mathrm{Sr}$ dates and $\mathrm{K}-\mathrm{Ar}$ dates are not consistent and why there is a large age variation among samples from small islets like Lutao and Lanhsu of Taiwan.

To combat the above mentioned problems, we have applied the fission-track dating (FTD) method, which depends only on temperature and thus is not affected by chemical disequilibrium (Gleadow and Brooks, 1979; Wagner, 1979), to systematically date the igneous rocks from this region. These new FTD dates offer coherent information regarding eruption ages, the effect of crustal contamination and the tectonic evolution of the northern part of the Taiwan-Luzon Arc. 


\section{Geological Background}

The Ryukyu-Taiwan-Luzon region is considered to be located in one of the most complex tectonic settings in the world. There are four main plate boundaries located in this area: (1) the Ryukyu Trench which is the plate boundary between Philippine Sea Plate and Eurasian Continent Plate; (2) the Manila Trench, where the South China Sea Plate is subducting eastward below the Luzon Arc; (3) the East Luzon Trough where the Philippine Sea Plate has just commenced to subduct westward beneath the Luzon micro-plate; and (4) the Philippine Trench, which is the plate boundary between Philippine Sea Plate and Philippine micro-plate (Fig. 1). The Luzon Arc is characterized by an unusual magmatic evolution as a result of the arc-continent collision zones at both ends (Knittel et al., 1988; Lo, 1989; Defant et al., 1989, 1990, 1991; Yang et al., 1992b; 1995; McDermott et al., 1993).

Defant et al., (1990) have identified 11 volcanic areas in the northern part of the Taiwan-Luzon Arc based on different volcanic centres. In this paper, we roughly divide the northern part of the Taiwan-Luzon Arc into the Taiwan, the Bashi, and the North Luzon Segments. The Taiwan Segment consists of the Coastal Range of eastern Taiwan, and the Bashi Segment of the islets, Lutao, Lanhsu and Hsiaolanhsu, off the southeastern coast of Taiwan, as well as the small islands north of Luzon. The North Luzon Segment comprises the eruption centres of northern Luzon.

\section{Taiwan Segment}

Detailed geology and stratigraphy of the Coastal Range of eastern Taiwan has been summarised by Teng et al. (1987). Two main volcanic centers have been identified in the central and southern Coastal Range, respectively (Lo, 1989). The eruption ages of the volcanic rocks (Tuluanshan Formation) are constrained by the overlying thick Pliocene-Pleistocene turbidite deposits (Fanshuliao and Paliwan Formation). This suggests that the volcanism in the Coastal Range had ceased since

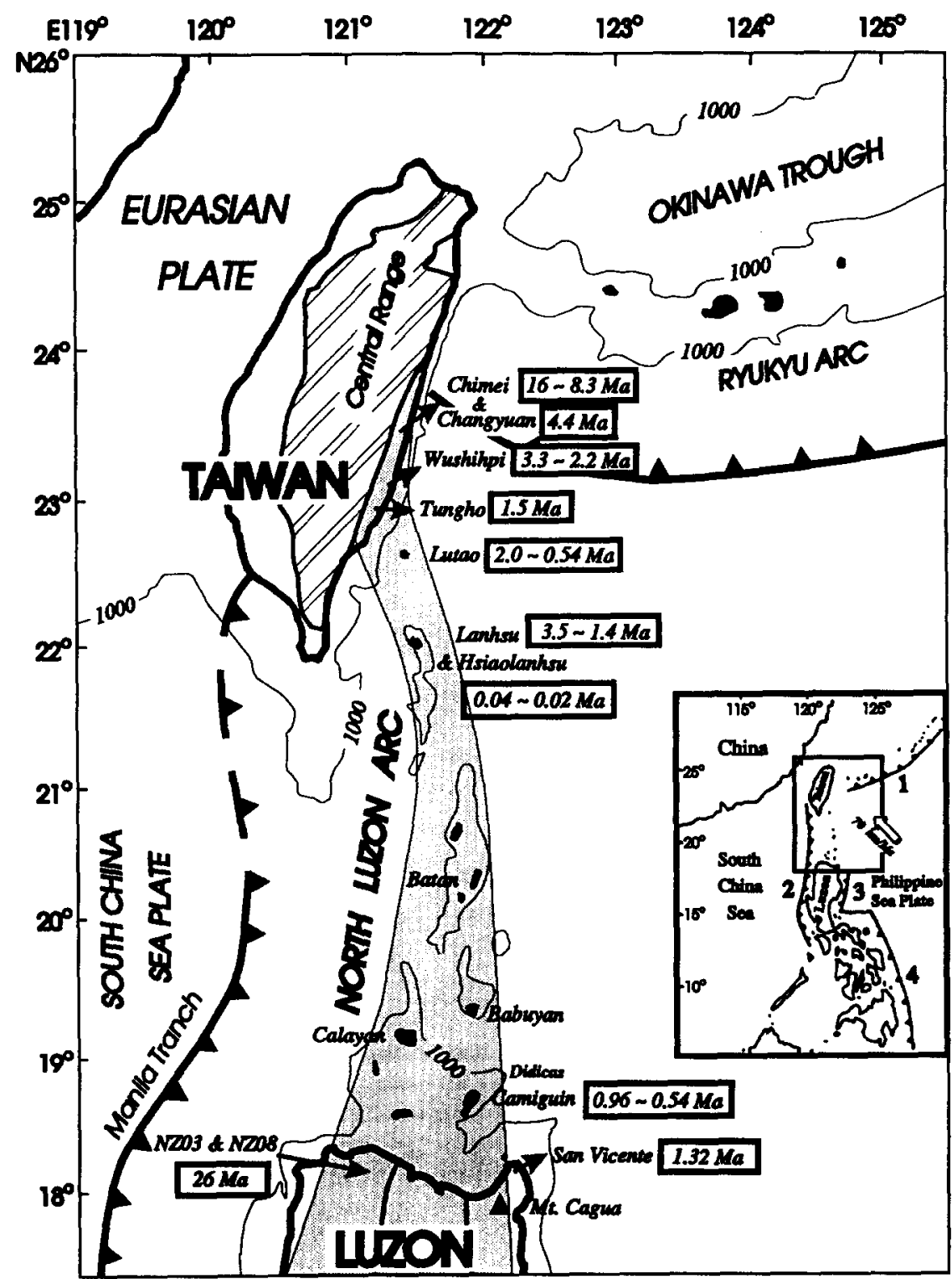

Fig. 1. Tectonic framework of the studied area. Four main plate boundaries are located within this region due to the subduction of (see inset) the South China Sea Plate and the West Philippine Sea Plate along the Ryukyu Trench (1), the Manila Trench (2), the East Luzon Trough (3), and the Philippine Trench (4). The ages shown in the frames are the FTD results obtained in this study. 
Table 1. Zircon age standard analyses for system calibration by the zeta approach

\begin{tabular}{|c|c|c|c|c|c|c|c|c|c|c|}
\hline \multirow[b]{2}{*}{ Standard } & \multirow{2}{*}{$\begin{array}{l}\text { Crystal } \\
\text { numbers }\end{array}$} & \multicolumn{2}{|c|}{ Spontaneous } & \multicolumn{2}{|c|}{ Induced } & \multirow[b]{2}{*}{$P\left(\chi^{2}\right)$} & \multirow[b]{2}{*}{ Glass } & \multicolumn{2}{|c|}{ Dosimeter } & \multirow[b]{2}{*}{$\zeta \pm 1 \sigma$} \\
\hline & & $\rho_{s}$ & $\left(N_{s}\right)$ & $\rho_{i}$ & $\left(N_{i}\right)$ & & & $\rho_{d}$ & $\left(N_{d}\right)$ & \\
\hline $\begin{array}{l}\overline{F C T}^{a} \\
\text { FCT }^{b}\end{array}$ & $\begin{array}{l}13 \\
13\end{array}$ & $\begin{array}{l}2.744 \\
1.695\end{array}$ & $\begin{array}{l}(997) \\
(705)\end{array}$ & $\begin{array}{l}2.447 \\
2.229\end{array}$ & $\begin{array}{l}(889) \\
(861)\end{array}$ & $\begin{array}{c}95 \% \\
-\end{array}$ & $\begin{array}{l}\text { NBS-610 } \\
\text { NBS-610 }\end{array}$ & $\begin{array}{l}0.8538 \\
1.3301\end{array}$ & $\begin{array}{l}(2066) \\
(2067)\end{array}$ & $\begin{array}{l}27.9 \pm 1.5 \\
27.0 \pm 1.5\end{array}$ \\
\hline
\end{tabular}

1. Analysed by external detector method; track densities $(\rho)$ are as measured in $\left(10^{6} \mathrm{tr} / \mathrm{cm}^{2}\right)$; numbers of counted tracks $(N)$ are shown in brackets.

2. $P\left(\chi^{2}\right)$ is probability of obtaining $\chi^{2}$ value for $v$ degrees of freedom, where $v=$ (number of crystals -1 ).

a. Independent age of standard used in this study is Fish Canyon Tuff (FCT) $=26.7 \pm 0.8 \mathrm{Ma}$ (Wagner, 1988).

b. Independent age of FCT used in Yang et al. (1992a) is $27.2 \pm 0.7 \mathrm{Ma}$ (Steven et al., 1967). $P\left(\chi^{2}\right)$ is unavailable because the source data of the analysis is lacking.

early Pliocene. Most geologists believe that the cessation of magmatism is related to the collision of Luzon Arc with the Eurasian plate and termination of oceanic subduction zone. Although some $\mathrm{K}-\mathrm{Ar}$ ages older than $20 \mathrm{Ma}$ have been recorded (Richard et al., 1986a), the time of the initial volcanic eruptions in the Coastal Range is still controversial, due to the alteration and the problem of inherited argon in some studied samples. FTD ages provided a minimum formation age of $16 \mathrm{Ma}$ for the Chimei Igneous Complex (Yang et al., 1988). Generally speaking, however, the magmatism commenced in early Miocene and stopped due to the arc-continent collision during late Miocene to early Pliocene.

\section{Bashi Segment}

Lutao is a volcanic islet located $34 \mathrm{~km}$ southeast of Taiwan. Because of its location just south of the already extinct Taiwan Segment, it is one of the important regions to study the process of arc-continent collision. The volcanic rocks forming the island range in composition from basalt to dacite. Biotite andesites, which are relatively rare in the Coastal Range, were deposited on basaltic rocks which form the basement of the exposed parts of Lutao. Some lavas with extremely high concentrations of large ion lithophile elements (LILE) were erupted during the final stages of the volcanism (Chen et al., 1990; Defant et al., 1990; Yang et al., 1992b) Disequilibria between phenocrysts in these lavas and between phenocrysts and whole rock compositions were documented by Lan et al. (1986), Chen (1989) and Wang and Chung (1990).

Lanhsu is a volcanic island mainly composed of andesitic lava flows and pyroclastic rocks. Diabasic dikes, gabbros and serpentinites also occur. The geochemical characteristics of the andesitic lavas, unlike the LILE-enriched volcanics of Lutao, are similar to those of the Coastal Range having tholeiitic to calc-alkaline series composition. A wide range of $\mathrm{K}-\mathrm{Ar}$ ages from $25.9 \mathrm{Ma}$ to $2.32 \mathrm{Ma}$ has been reported by Richard et al. (1986a) and Juang (1988). Some dated hornblende andesites, however, have suffered serious hydrothermal alteration. So far, the formation ages of the volcanics are still inconclusive.

Hsiaolanhsu is a small volcanic islet $\left(\sim 1 \mathrm{~km}^{2}\right)$ forming part of a well-preserved caldera. Although located only four kilometres from Lanhsu, it is composed of different rock types of distinct chemical composition. They are dominantly biotite-hornblende andesites with more enriched geochemical signatures compared to Lanhsu. Volcanism on the island represents the youngest magmatic manifestation of the Taiwanese part of the Taiwan-Luzon Arc and suggests that it is located south of the point where the arc is presently colliding with the continental margin. Available radiometric ages of samples from this islet are consistently less than $1 \mathrm{Ma}$ (Lan et al., 1986; Juang, 1988; Lo et al., 1994).

To the south the arc widens and more than 20 volcanic islands occur in this region. The islands Batan, Babuyan, Didicas, and Camiguin have been reported to be active volcanoes from north to south (Fig. 1). The others are extinct Miocene to Plio-Pleistocene volcanic islands. They are composed of various rock types ranging from basalt to dacite in composition and exhibiting a wide range of chemical composition from low-K tholeiitic to high-K calc-alkaline series. The geology of these islands has been described by Richard et al. (1986b); Jacques (1987); Defant et al. (1989, 1990) and Yang (1992).

\section{North Luzon Segment}

The North Luzon Segment can be divided into two main volcanic domains separated by the Cagayan Basin which is underlain Tertiary sediments. The Sierra Madre in the east is largely devoid of young volcanic activity except the Mt Cagua at the northern tip of that mountain range. It is believed that Cagua volcano is related to eastward subduction of the South China Sea Plate and built upon the Sierra Madre basement (Jacques, 1987; Defant et al., 1989, 1990). The Cordillera Central, covering the western portion of Luzon, has been the site of relatively extensive Miocene and Pliocene volcanism, but little is known about Quaternary activity (Knittel et al., 1984).

\section{Experimental Method and Results}

For fission-track dating analysis, we have collected 75 samples representing major rock types of this area. Zircons were separated by floatation and magnetic methods after the rock samples were crushed and sieved to retain grains smaller than 20 mesh. The detailed procedures used in this study have been described by Yang (1987) and Shieh (1990).

Zircon grains were mounted parallel to their c-axis in a PFA teflon sheet. "Grain-by-grain" and mica external detector techniques were adopted to obtain individual grain ages (Green, 1981; Krishnaswami et al., 1974). A zeta value (Hurford and Green, 1982; Green, 1985) of $27.9 \pm 1.5(1 \sigma)$ has been obtained in this study for the standard glass NBS-SRM 610 on the independent age zircons of Fish Canyon Tuff (Table 1). The calibration 
value of previously published FTD data performed in this laboratory, Department of Geology, National Taiwan University, is also given in Table 1 for comparison. The pooled age used in this study is calculated by pooling counts for the counted grains (Tagami et al., 1988; Brandon, 1993). Statistical errors were calculated from the Poisson uncertainties in fossil and induced tracks, and in counts used to determine the neutron dose as well (Green, 1981). The analytical procedures are following those of Yang et al. (1992a).

Hurford et al. (1984) dated individual zircon grains from Cretaceous sandstones. They calculated a normal age probability distribution for each grain and summed the probability distributions for all the grains in a sample to produce a so-called "composite probability density plot." It is used to identify source components and the thermal history in one area. Generally speaking, the youngest peak age of the plot indicates that last thermal event recorded by the zircons of the samples (Hurford et al., 1984; Kowallis et al., 1986; Liu, 1988; Yang et al., 1992a). Recently, Galbraith $(1988,1990)$ proposed a statistical based plot, so-called "radial plot" to check the homogeneity of grain FTD ages of a sample and see whether it is representative of two or more age groups (Fig. 2).

Forty-eight samples yielded sufficient zircons for FTD studies. The results, based on the recommendation by the Fission Track Working Group (Hurford, 1990), are given in Table 2. For each zircon grain, an age has been computed from the ratio of the density of the spontaneous tracks $\left(\rho_{\mathrm{s}}\right)$ and induced tracks $\left(\rho_{\mathrm{i}}\right)$ and the thermal neutron doses $(\phi)$ following the equation given by Liu (1982). When more than one zircon grain is available for a given sample one can pool all the tracks counted in several grains and compute a pooled age. We assume that associated with each grain is a probability density distribution. The peak is its single grain age and whose width is related to the uncertainty associated with that age. When there are enough grains for a sample we can superpose the probability density distributions for individual grains and plot a composite distribution (Hurford et al., 1984; Brandon, 1992). For samples having more than three grains (in most cases there are more than five grains), their composite distributions are plotted. For zircon crystals crystallized from the same magma or having fission-track completely annealed during eruption, their composite age distributions should approximate a normal distribution with a peak consistent with the pooled age of all grains. Examination of the plots revealed that some samples do exhibit this idealised behaviour. An example (TH-02) is shown in Fig. $3 \mathrm{~A}$, where the data are homogenous in the radial plot. In addition, the composite probability density plot is close to normal distribution and its peak age of $1.40 \mathrm{Ma}$ agrees with the pooled age of $1.45 \pm 0.1 \mathrm{Ma}$. Thus, in this case there is little doubt that the pooled age can be interpreted as the eruption age. Sample CM-FT7 with FTD age of $16 \pm 1 \mathrm{Ma}$ also exhibits such a normal distribution. This sample, however, had suffered intense hydrothermal alteration (Yang et al., 1988). The pooled age, in this case, has to be considered to represent the time of last hydrothermal activity which has totally reset the records of former thermal events.

Nevertheless, most samples in this study are heterogeneous and do not have normal distributions. Two examples are shown in Fig. 3B and 3C. Sample LY5-01 and NZ-08 have a clear bimodal distribution. This suggests the presence of older zircon grains that have been only partially reset during their residence in the magma, thus retaining memory of earlier heating events. In fact, many samples have peak ages outside the $2 \sigma$ uncertainty of their pooled ages. It is believed that the youngest peak date of a multi-peak age distribution represents the record of the final cooling of their host

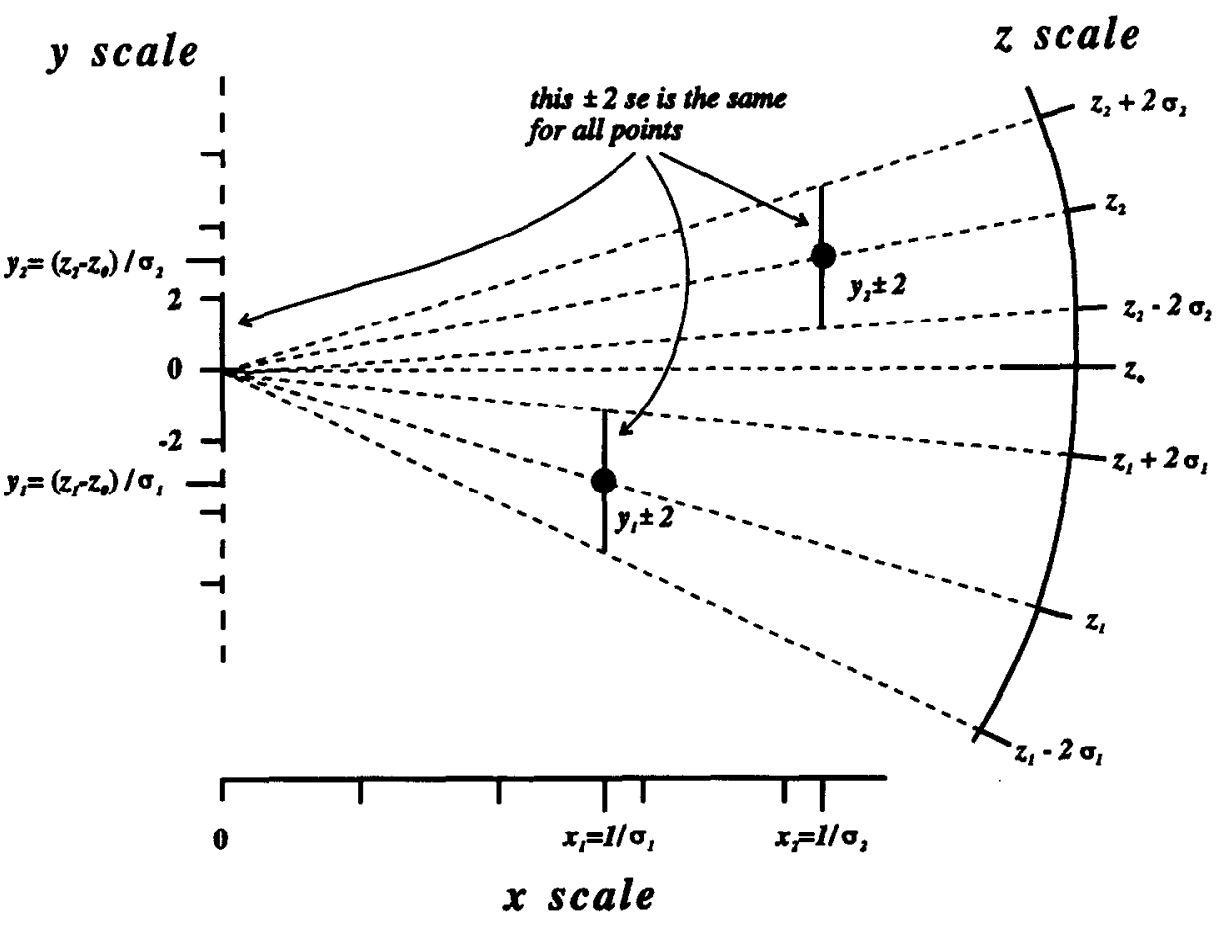

Fig. 2. Principle of the radial plot (after Galbraith, 1988). An estimate $z$ with standard error $s$ is plotted as the point $(x, y)$ where $x=1 / s$ and $y=(z-z o) / s$ for some $z o$ chosen so the average $y$ is near 0 . Each estimate has unit standard error on the $y$ scale. Points with larger $x$ have higher precision. To read off the values of $z$ and $z \pm 2$, extrapolate lines from $(0,0)$ through $(x, y)$ and from $(0,0)$ through $(x, y \pm 2)$ to the $z$ scale. 
(A) $\mathrm{TH}-02$
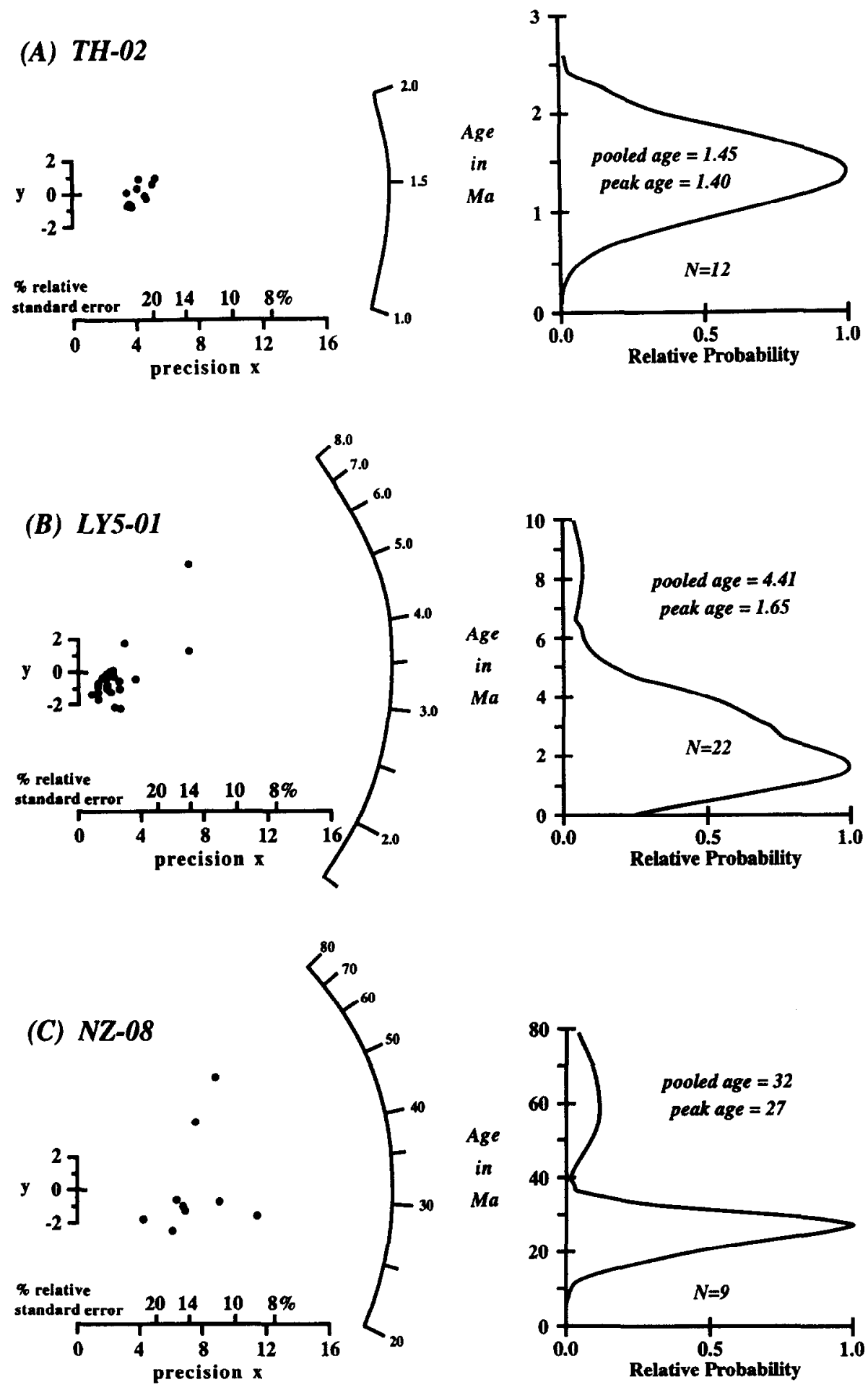

Fig. 3. Plots of representative examples of FTD obtained in this study. The radial plots are shown at left side and explained in Fig. 2. The abscissa of the composite probability density plot, which plotted at right side, is the relative probability normalized to the highest peak (denoted by full in the diagram). The number $N$ is the number of zircon grains counted for the sample. (A) Homogenous data with normal distribution with pooled age equal to peak age. Except for a few hydrothermally altered and intrusive rocks, the age is assumed to represent the eruption age of the sample. (B) and (C) Heterogeneous grain age data with skewed distribution with a tendency towards a bi-modal distribution. The pooled age is different from the peak age, and it cannot represent the time volcanic eruption.

lavas. The other high peak dates probably represent the partially annealed dates of former thermal events recorded in xenocrystal zircons (Kowallis et al., 1986; Wang and Chen, 1990; Yang et al., 1992a; Brandon and Vance, 1993).

Many methods, e.g. finite mixture model (Galbraith and Green, 1990); $\chi^{2}$ age method and Gaussian peakfitting method (Brandon, 1992), have been proposed to extract the youngest group of ages from heterogeneous data to represent the last thermal event of the sample. In order to estimate eruption ages from these data we have applied the so-called $\chi^{2}$ age method of Brandon (1992) and Yang et al. (1992a) in this study. In this method, zircon grains are first sorted in order of increasing age (e.g. Table 3). Starting from the youngest grain, the next youngest grain is added to form a group and a pooled 
age is computed for these two grains ("sum age" in the Table 3). A $\chi^{2}$ test is then performed to check whether, given the ages for individual grains in the group and the sum age, there is a significant chance that the entire group was derived from a single event. This process is repeated when each grain is added to the group. When the statistical significance (the $P\left(\chi^{2}\right)$ in Table 3 ) drops below $1 \%$, we consider that grain and all older grains to have been completely reset during their residence in the magma. Hence they should not be included in the calculation of the eruption age. The sum age of all grains up to that point, termed " $\chi$ 2 age", which is a better estimate of the eruption age than the pooled age, is shown in Table 4. Except for a few samples, the $\chi^{2}$ ages for the remaining samples agree, within the $\chi^{2}$ uncertainty, with the corresponding peak ages. This consistency supports our interpretation of $\chi^{2}$ ages as eruption ages for the volcanics.

The very young ages of Hsiaolanhsu lavas ( $<1 \mathrm{Ma}$; Lan et al., 1986; Juang, 1988; Lo et al., 1994) might be difficult to date by FTD. Fortunately, the uranium contents of the zircons are high enough to yield tracks for counting. However, some zircon grains of the samples SLY-01, SLY-06 have low $U$ contents and are too young to produce spontaneous tracks even after heavy etching. Consequently the grain-by-grain method cannot be applied to these samples. As a compromise, a total area population method (Tagami et al., 1988) is used to calculate the zircon FTD ages. Therefore, only pooled ages are given in Table 4 .

In Table 4 we further list the "inherited age", which is the oldest grain age that failed the $\chi^{2}$ test. This age is interpreted as the lower limit for the earliest heating events that are probably partially annealed and still recorded in zircon tracks.

\section{Discussion}

Although in most cases the $\chi^{2}$ ages can be interpreted as eruption ages of the volcanics, any later thermal activity that may have affected the fission-track clocks must be carefully examined. Some of our samples show effects of hydrothermal alteration, which may have reset the tracks totally or partially. For example, CM-FT7, CM-H1, CY02-1, LY5-02 and LY5-17 are hydrothermally altered and the $\chi^{2}$ ages should be interpreted as last thermal event rather than eruption ages. In particular, the composite probability plots of LY5-02 and LY5-17 show multi-peak patterns. This implies that hydrothermal activities still went on at about $0.26 \mathrm{Ma}$ in Lanhsu, and the temperature of the last event was not

Table 2. Results of zircons FTD* of North Luzon Arc volcanics

\begin{tabular}{|c|c|c|c|c|c|c|c|c|c|c|}
\hline \multirow{2}{*}{$\begin{array}{l}\text { Sample and } \\
\text { locality }\end{array}$} & \multirow{2}{*}{$\begin{array}{l}\text { Counted } \\
\text { grains }\end{array}$} & \multicolumn{2}{|c|}{ Spontaneous } & \multicolumn{2}{|c|}{ Induced } & \multirow{2}{*}{$\begin{array}{c}P\left(\chi^{2}\right) \\
(\%) \\
\end{array}$} & \multicolumn{2}{|c|}{ Dosimeter } & \multirow[b]{2}{*}{ Age $\pm 1 \sigma$} & \multirow{2}{*}{$\begin{array}{c}\text { Major mafic \# } \\
\text { phenocrysts }\end{array}$} \\
\hline & & $\rho_{s}$ & $\left(N_{s}\right)$ & $\rho_{i}$ & $\left(N_{i}\right)$ & & $\rho_{d}$ & $\left(N_{d}\right)$ & & \\
\hline \multicolumn{11}{|c|}{ Taiwan } \\
\hline Coastal range & & & & & & & & & & \\
\hline CM-FT7 (Chimei) & 19 & 2.580 & (694) & 3.200 & (706) & $<1$ & 0.654 & (1907) & $16.7 \pm 1.0$ & Cpx \\
\hline CM-HI (Chimei) & 13 & 2.540 & (1346) & 4.833 & (2073) & $<1$ & 0.852 & $(4122)$ & $12.5 \pm 0.5$ & Px \\
\hline CY02-1 (Changyuan) & 17 & 0.307 & (184) & 1.161 & $(695)$ & $<1$ & 0.765 & (2313) & $5.7 \pm 0.5$ & altered \\
\hline WSP-1 (Wushihpi) & 16 & 0.260 & $(65)$ & 3.337 & $(834)$ & $<1$ & 1.220 & $(2000)$ & $2.7 \pm 0.3$ & $\mathrm{Cpx}+\mathrm{Opx}+\mathrm{Ol}$ \\
\hline WSP-2 (Wushihpi) & 13 & 0.165 & (32) & 1.939 & (377) & 35 & 0.116 & (2013) & $3.3 \pm 0.6$ & $\mathrm{Cpx}+\mathrm{Opx}+\mathrm{Ol}$ \\
\hline Th-01 (Tungho) & 12 & 0.309 & $(259)$ & 7.249 & $(6084)$ & $<1$ & 0.112 & $(2040)$ & $1.6 \pm 0.1$ & Bi-tuff \\
\hline TH-02 (Tungho) & 12 & 0.279 & (209) & 7.298 & $(5475)$ & 21 & 0.112 & (2040) & $1.5 \pm 0.1$ & Bi-tuff \\
\hline \multicolumn{11}{|l|}{ Lanhsu } \\
\hline LY5-01 & 22 & 0.234 & $(228)$ & 2.176 & $(2123)$ & $<1$ & 1.135 & $(2059)$ & $3.4 \pm 0.3$ & $\mathrm{Hb}$ \\
\hline LY5-02 & 7 & 0.428 & (166) & 3.852 & (1494) & $<1$ & 0.854 & (2066) & $2.7 \pm 0.2$ & $\mathrm{Hb}$ \\
\hline LY 5-03 & 24 & 0.309 & $(320)$ & 4.130 & (4278) & $<1$ & 1.135 & (2059) & $2.4 \pm 0.2$ & $\mathrm{Hb}$ \\
\hline LY5-04 & 23 & 0.282 & $(218)$ & 2.463 & (1904) & $<1$ & 0.854 & $(2066)$ & $2.7 \pm 0.2$ & $\mathrm{Hb}$ \\
\hline LY 5-05 & 8 & 1.916 & $(252)$ & 5.398 & $(710)$ & $<1$ & 0.854 & $(2066)$ & $8.5 \pm 0.7$ & Cpx \\
\hline LY5-07 & 7 & 0.504 & (191) & 4.120 & (1562) & $<1$ & 0.854 & $(2066)$ & $2.9 \pm 0.2$ & $\mathrm{Hb}+\mathrm{Cpx}$ \\
\hline LY5-08 & 20 & 0.247 & (99) & 3.655 & (1463) & $<1$ & 1.135 & (2059) & $2.2 \pm 0.2$ & $\mathrm{Hb}+\mathrm{Px}+\mathrm{Ol}$ \\
\hline LY5-10 & 6 & 0.208 & $(24)$ & 3.129 & $(361)$ & 39 & 1.135 & $(2059)$ & $2.1 \pm 0.5$ & $\mathrm{Hb}+\mathrm{Cpx}$ \\
\hline LY 5-15B & 14 & 0.497 & $(295)$ & 3.069 & $(1820)$ & $<1$ & 0.854 & (2066) & $3.9 \pm 0.3$ & $\mathbf{H b}$ \\
\hline LY5-16B & 3 & 1.137 & $(91)$ & 14.214 & (1138) & $<1$ & 1.135 & (2059) & $2.5 \pm 0.3$ & $\mathrm{Hb}$ \\
\hline LY5-17 & 5 & 0.673 & (48) & 9.703 & $(692)$ & $<1$ & 0.854 & (2066) & $1.7 \pm 0.3$ & $\mathrm{Hb}+\mathrm{Cpx}$ \\
\hline LY5-19 & 2 & 0.330 & (15) & 3.567 & (162) & 3 & 0.854 & $(2066)$ & $2.2 \pm 0.6$ & $\mathrm{Hb}$ \\
\hline LY5-20A & 3 & 0.507 & (23) & 3.721 & (169) & 92 & 0.854 & (2066) & $3.3 \pm 0.7$ & $\mathrm{Hb}$ \\
\hline \multicolumn{5}{|l|}{ Hsiaolanhsu } & (8066) & - & 1.137 & $(2063)$ & $0.04 \pm 0.01$ & $\mathrm{Hb}+\mathrm{Bi}$ \\
\hline $\begin{array}{l}\text { SLY }-01 \dagger \\
\text { SLY }-06+\end{array}$ & $\begin{array}{l}13 \\
19\end{array}$ & 0.0050 & (7) & $\begin{array}{l}9.001 \\
8.594\end{array}$ & $(11,940)$ & - & 1.137 & (2063) & $0.02 \pm 0.01$ & Tuff \\
\hline & & & & & Philippines & & & & & \\
\hline \multicolumn{11}{|l|}{ Camiguin Island } \\
\hline CMG-10 & 12 & 0.0097 & (29) & 2.454 & (7336) & 77 & 4.258 & $(2576)$ & $0.54 \pm 0.10$ & Cpx \\
\hline CMG-15A & 9 & 0.0278 & (33) & 3.440 & (4091) & 3 & 4.258 & $(2576)$ & $0.96 \pm 0.17$ & $\mathbf{P x}$ \\
\hline \multicolumn{11}{|l|}{ Northern Luzon } \\
\hline NZ-08+ & 9 & 1.496 & (692) & 5.621 & $(2600)$ & $<1$ & 4.258 & $(2576)$ & $31.7 \pm 1.5$ & Hb \\
\hline SVT-02 (San Vincete) & 2 & 0.848 & (77) & 3.149 & $(286)$ & $<1$ & 1.101 & $(2220)$ & $8.3 \pm 1.1$ & Tuff \\
\hline
\end{tabular}

* External detector method used. Unit and symbols used are as in Table 1 .

$\dagger$ Population method used (see discussion in the text).

$\ddagger$ Granitoid basement of North Luzon; mainly composed of quartz, feldspars and hornblende.

\# $\mathrm{Hb}$ : hornblende; Px: pyroxene; Bi: biotite; Opx: ortho-pyroxene; Cpx: clino-pyroxene; Ol: olivine. 
Table 3. Zircon FTD grain ages of representative samples from North Luzon Arc

\begin{tabular}{|c|c|c|c|c|}
\hline $\begin{array}{l}\text { TH }-02 \\
\text { no. }\end{array}$ & $\begin{array}{l}\text { Grain age } \\
(\mathrm{Ma} \pm \mathrm{l} \sigma)\end{array}$ & $\begin{array}{l}\text { eak age } \\
(\mathrm{Ma})\end{array}$ & $P\left(\chi^{2}\right) \#$ & $\begin{array}{l}\text { Sum age } \\
(\mathrm{Ma} \pm 1 \sigma)\end{array}$ \\
\hline $\begin{array}{l}1 \\
2 \\
3 \\
4 \\
5 \\
6 \\
7 \\
8 \\
9 \\
10 \\
11 \\
12 \\
\text { Total } \\
\end{array}$ & $\begin{array}{l}1.17 \pm 0.32 \\
1.17 \pm 0.34 \\
1.20 \pm 0.33 \\
1.24 \pm 0.35 \\
1.37 \pm 0.30 \\
1.42 \pm 0.32 \\
1.49 \pm 0.44 \\
1.50 \pm 0.44 \\
1.59 \pm 0.39 \\
1.64 \pm 0.33 \\
1.75 \pm 0.34 \\
1.81 \pm 0.44 \\
1.45 \pm 0.11 \\
\end{array}$ & $\begin{array}{l}1.20 \\
1.20 \\
1.20 \\
1.20 \\
1.20 \\
1.30 \\
1.30 \\
1.30 \\
1.30 \\
1.30 \\
1.40 \\
1.40 \\
1.40 \\
\end{array}$ & $\begin{array}{c}100 \\
100 \\
99 \\
99 \\
98 \\
97 \\
94 \\
91 \\
82 \\
63 \\
41 \\
21 \\
T\left(\chi^{2}\right)= \\
\end{array}$ & $\begin{array}{l}1.17 \pm 0.32 \\
1.17 \pm 0.23 \\
1.18 \pm 0.19 \\
1.19 \pm 0.17 \\
1.24 \pm 0.15 \\
1.27 \pm 0.14 \\
1.30 \pm 0.13 \\
1.31 \pm 0.13 \\
1.34 \pm 0.12 \\
1.38 \pm 0.11 \\
1.43 \pm 0.11 \\
1.45 \pm 0.11 \\
1.45 \pm 0.11^{*}\end{array}$ \\
\hline $\begin{array}{l}\text { LY5-01 } \\
\text { no. }\end{array}$ & $\begin{array}{l}\text { Grain age } \\
(\mathrm{Ma} \pm 1 \sigma)\end{array}$ & $\begin{array}{c}\text { Peak age } \\
(\mathrm{Ma})\end{array}$ & $P\left(\chi^{2}\right)$ & $\begin{array}{c}\text { Sum age } \\
(\mathrm{Ma} \pm 1 \sigma)\end{array}$ \\
\hline $\begin{array}{l}1 \\
2 \\
3 \\
4 \\
5 \\
6 \\
7 \\
8 \\
9 \\
10 \\
11 \\
12 \\
13 \\
14 \\
15 \\
16 \\
17 \\
18 \\
19 \\
20 \\
21 \\
22 \\
\text { Total } \\
\end{array}$ & $\begin{array}{l}0.84 \pm 0.85 \\
0.99 \pm 0.71 \\
1.32 \pm 0.96 \\
1.35 \pm 0.56 \\
1.49 \pm 0.54 \\
1.82 \pm 1.32 \\
1.91 \pm 0.88 \\
1.99 \pm 1.45 \\
1.99 \pm 1.02 \\
2.19 \pm 1.13 \\
2.31 \pm 0.85 \\
2.72 \pm 1.64 \\
2.76 \pm 1.02 \\
2.76 \pm 1.44 \\
3.00 \pm 0.81 \\
3.03 \pm 1.29 \\
3.18 \pm 1.67 \\
3.38 \pm 1.59 \\
3.53 \pm 1.52 \\
4.06 \pm 0.58 \\
6.03 \pm 1.99 \\
8.60 \pm 1.22 \\
3.41 \pm 0.25\end{array}$ & $\begin{array}{l}0.84 \\
0.93 \\
1.01 \\
1.19 \\
1.30 \\
1.32 \\
1.36 \\
1.37 \\
1.40 \\
1.42 \\
1.47 \\
1.49 \\
1.52 \\
1.54 \\
1.57 \\
1.60 \\
1.61 \\
1.63 \\
1.65 \\
1.65 \\
1.65 \\
1.65 \\
1.65 \\
\end{array}$ & $\begin{array}{c}100 \\
89 \\
92 \\
92 \\
91 \\
90 \\
84 \\
78 \\
69 \\
58 \\
41 \\
25 \\
10 \\
4 \\
<1 \\
<1 \\
<1 \\
<1 \\
<1 \\
<1 \\
<1 \\
<1 \\
T\left(\chi^{2}\right)=\end{array}$ & $\begin{array}{l}0.84 \pm 0.85 \\
0.93 \pm 0.55 \\
1.06 \pm 0.48 \\
1.20 \pm 0.37 \\
1.31 \pm 0.31 \\
1.35 \pm 0.30 \\
1.43 \pm 0.29 \\
1.46 \pm 0.28 \\
1.51 \pm 0.27 \\
1.56 \pm 0.27 \\
1.66 \pm 0.66 \\
1.70 \pm 0.26 \\
1.80 \pm 0.25 \\
1.84 \pm 0.25 \\
2.00 \pm 0.24 \\
2.05 \pm 0.24 \\
2.09 \pm 0.24 \\
2.13 \pm 0.24 \\
2.19 \pm 0.24 \\
2.65 \pm 0.23 \\
2.75 \pm 0.23 \\
3.41 \pm 0.25 \\
1.84 \pm 0.25 *\end{array}$ \\
\hline $\begin{array}{l}\text { NZ-08 } \\
\text { no. } \\
\end{array}$ & $\begin{array}{l}\text { Grain age } \\
(\mathrm{Ma} \pm 1 \sigma)\end{array}$ & $\begin{array}{c}\text { Peak age } \\
\text { (Ma) }\end{array}$ & $P\left(\chi^{2}\right)$ & $\begin{array}{c}\text { Sum age } \\
(\mathrm{Ma} \pm 1 \sigma)\end{array}$ \\
\hline $\begin{array}{c}1 \\
2 \\
3 \\
4 \\
5 \\
6 \\
7 \\
8 \\
9 \\
\text { Total }\end{array}$ & $\begin{array}{l}20.4 \pm 4.8 \\
20.8 \pm 3.5 \\
25.8 \pm 3.8 \\
26.9 \pm 4.0 \\
27.3 \pm 2.5 \\
28.5 \pm 4.6 \\
29.0 \pm 3.2 \\
54.0 \pm 7.3 \\
69.1 \pm 8.1 \\
31.7 \pm 4.5\end{array}$ & $\begin{array}{l}20.4 \\
20.7 \\
22.0 \\
23.5 \\
26.3 \\
26.6 \\
27.1 \\
27.1 \\
27.1 \\
27.1\end{array}$ & $\begin{array}{c}100 \\
96 \\
55 \\
38 \\
15 \\
7 \\
3 \\
<1 \\
<1 \\
T\left(\chi^{2}\right)=\end{array}$ & $\begin{array}{l}20.4 \pm 4.8 \\
20.6 \pm 2.8 \\
22.8 \pm 2.3 \\
24.0 \pm 2.0 \\
25.4 \pm 1.6 \\
25.8 \pm 1.5 \\
26.4 \pm 1.4 \\
28.5 \pm 1.4 \\
31.7 \pm 1.5 \\
26.4 \pm 1.4\end{array}$ \\
\hline $\begin{array}{l}\text { SVT-02 } \\
\text { no. }\end{array}$ & $\begin{array}{l}\text { Grain age } \\
(\mathrm{Ma} \pm 1 \sigma)\end{array}$ & $\begin{array}{c}\text { Peak age } \\
\text { (Ma) }\end{array}$ & $P\left(\chi^{2}\right)$ & $\begin{array}{c}\text { Sum age } \\
(\mathrm{Ma} \pm 1 \sigma)\end{array}$ \\
\hline $\begin{array}{l}1 \\
2\end{array}$ & $\begin{array}{l}1.32 \pm 0.50 \\
67.5 \pm 15.0\end{array}$ & $\begin{array}{l}1.32 \\
1.32\end{array}$ & $\begin{array}{l}100 \\
<1\end{array}$ & $\begin{array}{l}1.32 \pm 0.50 \\
8.29 \pm 1.10\end{array}$ \\
\hline
\end{tabular}

1. The single grain age is determined by the desities of spontaneous and induced tracks.

2. The peak age is the age with greatest probability in the composite probability density plot.

3. It is the age pooling track that counts for the counted grain and the grains with younger ages.

\# The statistical significance of the $\chi^{2}$ test between the age and the group of younger ages.

"So-called " $\chi^{2}$ age" is the oldest sum age which passed the $\chi^{2}$ test a $1 \%$ level. high enough to completely reset the record of former events. In contrast, hydrothermal activity in the Chimei area (CM-FT7), Coastal Range of eastern Taiwan appeared to have been strong enough to completely reset the records of former thermal events. The FTD age indicates that the Chimei Igneous Complex was formed prior to $16 \mathrm{Ma}$.

It is worth noting that NZ-08 is the granitic rock from northern Luzon basement. It shows bimodal distribution in the probability density plot (Fig. 3C). The former record (inherited age of $69 \mathrm{Ma}$ ) may represent the uplifting age or the formation age of the basement. This age is consistent with the inherited age (68 Ma) of SVT-02 (Tables 3 and 4), suggesting magmatic activity in North Luzon during the late-Cretaceous epoch. Meanwhile, the youngest peak age $(27 \mathrm{Ma})$ of NZ-08 is consistent with the eruption age of nearby arc-related basalt (NZ-03, $26 \pm 2 \mathrm{Ma}$ of $\mathrm{K}-\mathrm{Ar}$ age; Yang, 1992). This implies that the last thermal event that occurred in this area was the magmatism of Luzon Arc, which may partially reset the memory of the early thermal events of the basement rocks.

Although only two zircon grains could be separated for FTD from a tuffaceous sandstone, SVT-02, we obtained two extremely different FTD ages (Table 3 ). One is $1.32 \pm 0.41 \mathrm{Ma}$, consistent with the $\mathrm{K}-\mathrm{Ar}$ ages of the lava of nearby $\mathrm{Mt}$ Cagua $(1.48 \sim 0.32 \mathrm{Ma}$; Jacques, 1987). The other is $68 \pm 15 \mathrm{Ma}$, which is consistent with the inherited age of NZ-08 (Tables 3 and 4). This suggests that Sierra Madre and Cordillera Central of North Luzon may have similar basement; furthermore, there was no evidence for magmatism prior to the eruption of Mt Cagua in Sierra Madre of northern Luzon.

\section{Implications of the inherited dates}

The fission-tracks in minerals may be stable for a long period of time. Because they are not affected by pressure, solutions and ionization, and are only sensitive to temperature (Fleisher et al., 1975; Zaun and Wagner, 1985). In FTD technique, the closure temperature of a mineral is the temperature at which $50 \%$ of tracks are annealed. Usually higher cooling rates and a short duration of heating lead to higher closure temperatures (Wagner and Storzer, 1972; Wagner, 1979). For example, the closure temperature of zircon can range from $450^{\circ} \mathrm{C}$ for a short duration $\left(10^{4}-10^{6} \mathrm{~min}\right)$ to $200^{\circ} \mathrm{C}$ for a long duration $\left(10^{6}-10^{9} \mathrm{yrs}\right)$, respectively (Haack, 1977; Sharma et al., 1980). Bal et al. (1983) have shown experimentally that the fission tracks of zircon can be totally annealed at a temperature of about $675-900^{\circ} \mathrm{C}$ in an hour.

Generally speaking, the fission track clock starts to run when magmas are cooled below the closure temperature. The eruption temperatures are usually higher than $800^{\circ} \mathrm{C}$ but rapidly drop down below the closure temperature of zircon in few days to years. However, the temperature of pyroclastic eruption $\left(500-600^{\circ} \mathrm{C}\right)$ is lower than that of lava flows and cools faster. Pyroclastic deposits often capture fragments of basement and/or the products of former eruptions with zircons retaining a record of their pre-eruption history. In this fashion, the composite probability density plot of zircons in the pyroclastic rocks may exhibit a multi-peak distribution, with the youngest peak registering the eruption event. 
Tsanyao F. Yang et al.

Table 4. The corrected results of FTD dates of North Luzon Arc volcanics

\begin{tabular}{|c|c|c|c|c|}
\hline Sample and locality & $\begin{array}{l}\text { Pooled age } \\
\quad(\mathrm{Ma} \pm 1 \sigma)\end{array}$ & $\begin{array}{c}\text { Peak age } \\
\text { (Ma) }\end{array}$ & $\begin{array}{c}\chi^{2} \text { age }^{1} \\
(\mathrm{Ma} \pm 1 \sigma)\end{array}$ & $\begin{array}{c}\text { Inherited age } \\
\text { (Ma) }\end{array}$ \\
\hline \multicolumn{5}{|c|}{ Taiwan } \\
\hline \multicolumn{5}{|l|}{ Coastal Range } \\
\hline CM-FT7 (Chimei) & $17 \pm 1$ & 16 & $16 \pm 1+$ & 21 \\
\hline CM-H1 (Chimei) & $13 \pm 1$ & 7.3 & $8.3 \pm 0.6 \dagger$ & 19 \\
\hline CY02-1 (Changyuan) & $5.7 \pm 0.5$ & 5.3 & $4.4 \pm 0.6 \dagger$ & 18 \\
\hline WSP-1 (Wushihpi) & $2.7 \pm 0.3$ & 2.0 & $2.2 \pm 0.4$ & 4.5 \\
\hline WSP-2 (Wushihpi) & $3.6 \pm 0.6$ & 2.7 & $3.3 \pm 0.6$ & - \\
\hline TH-01 (Tungho) & $1.6 \pm 0.1$ & 1.4 & $1.5 \pm 0.1$ & 3.2 \\
\hline TH-02 (Tungho) & $1.5 \pm 0.1$ & 1.4 & $1.5 \pm 0.1$ & - \\
\hline \multicolumn{5}{|l|}{ Lutao \# } \\
\hline LT2-02 & $2.0 \pm 0.2$ & 1.5 & $1.5 \pm 0.2$ & 4.6 \\
\hline LT2-03A & $2.0 \pm 0.4$ & 0.92 & $2.0 \pm 0.4$ & - \\
\hline LT2-05 & $1.8 \pm 0.6$ & 一 & - & - \\
\hline LT2-06B & $1.8 \pm 0.4$ & 1.2 & $1.8 \pm 0.4$ & - \\
\hline LT2-07 & $50 \pm 10$ & - & - & 50 \\
\hline LT2-09 & $1.7 \pm 0.2$ & 1.7 & $1.6 \pm 0.2$ & 2.0 \\
\hline LT2-13A & $1.2 \pm 0.2$ & 0.91 & $0.80 \pm 0.17$ & 2.4 \\
\hline LT2-14 & $0.92 \pm 0.16$ & 0.66 & $0.79 \pm 0.17$ & 1.6 \\
\hline LT2-15 & $1.5 \pm 0.2$ & 1.0 & $0.93 \pm 0.16$ & 3.8 \\
\hline LT2-17 & $1.1 \pm 0.1$ & 0.95 & $0.81 \pm 0.10$ & 2.8 \\
\hline LT2-19D & $1.4 \pm 0.1$ & 1.0 & $1.1 \pm 0.1$ & 3.7 \\
\hline LT2-20 & $1.2 \pm 0.2$ & 1.0 & $1.1 \pm 0.2$ & 2.4 \\
\hline LT2-21 & $2.6 \pm 0.3$ & 1.5 & $1.4 \pm 0.3$ & 15 \\
\hline LT2-22 & $3.3 \pm 0.3$ & 1.8 & $1.7 \pm 0.3$ & 39 \\
\hline LT2-25 & $0.75 \pm 0.09$ & 0.55 & $0.61 \pm 0.10$ & 1.4 \\
\hline LT2-26A & $0.80 \pm 0.31$ & - & - & - \\
\hline LT2-31 & $1.2 \pm 0.1$ & 0.80 & $0.99 \pm 0.14$ & 2.1 \\
\hline LT2-31A & $1.2 \pm 0.1$ & 1.1 & $1.0 \pm 0.1$ & 1.8 \\
\hline LT2-32 & $0.78 \pm 0.11$ & 0.53 & $0.54 \pm 0.11$ & 2.7 \\
\hline LT2-33 & $2.1 \pm 0.4$ & 1.6 & $2.0 \pm 0.4$ & 3.7 \\
\hline LT2-35 & $1.0 \pm 0.3$ & 0.74 & $1.0 \pm 0.3$ & - \\
\hline LT2-38 & $1.5 \pm 0.1$ & 0.98 & $1.2 \pm 0.1$ & 2.7 \\
\hline \multicolumn{5}{|l|}{ Lanhsu } \\
\hline LY 5-01 & $3.4 \pm 0.3$ & 1.7 & $1.8 \pm 0.3$ & 8.6 \\
\hline LY 5-02 & $2.7 \pm 0.2$ & 0.80 & $1.2 \pm 0.2 \uparrow$ & 4.8 \\
\hline LY5-03 & $2.4 \pm 0.2$ & 2.2 & $1.9 \pm 0.2$ & 4.7 \\
\hline LY 5-04 & $2.7 \pm 0.2$ & 2.5 & $2.4 \pm 0.2$ & 6.2 \\
\hline LY 5-05 & $8.5 \pm 0.7$ & 1.3 & $1.6 \pm 0.3$ & 21 \\
\hline LY5-07 & $2.9 \pm 0.2$ & 1.3 & $1.4 \pm 0.4$ & 4.8 \\
\hline LY 5-08 & $2.2 \pm 0.2$ & 1.3 & $1.5 \pm 0.2$ & 5.0 \\
\hline LY 5-10 & $2.1 \pm 0.5$ & 1.7 & $2.1 \pm 0.5$ & - \\
\hline LY5-15B & $3.9 \pm 0.3$ & 3.6 & $3.5 \pm 0.3$ & 6.2 \\
\hline LY5-16B & $2.5 \pm 0.3$ & - & 二 & - \\
\hline LY5-17 & $1.7 \pm 0.3$ & 0.23 & $0.26 \pm 0.15 \dagger$ & 3.6 \\
\hline LY5-19 & $2.2 \pm 0.6$ & & - & - \\
\hline LY5-20A & $3.3 \pm 0.7$ & 3.16 & $3.3 \pm 0.7$ & - \\
\hline \multicolumn{5}{|l|}{ Hsiaolanhsu } \\
\hline SLY-01* & $0.04 \pm 0.01$ & - & - & - \\
\hline \multirow[t]{2}{*}{ SLY-06* } & $0.02 \pm 0.01$ & - & - & - \\
\hline & \multicolumn{3}{|c|}{ Philippines } & \\
\hline \multicolumn{5}{|l|}{ Camiguin Island } \\
\hline CMG-10 & $0.54 \pm 0.10$ & 0.49 & $0.54 \pm 0.10$ & - \\
\hline CMG-15A & $0.96 \pm 0.17$ & 0.73 & $0.96 \pm 0.17$ & - \\
\hline \multicolumn{5}{|l|}{ Northern Luzon } \\
\hline $\mathrm{NZ}-08$ & $32 \pm 2$ & 27 & $26 \pm 1 \ddagger$ & 69 \\
\hline SVT-02 (San Vicente) & $8.3 \pm 1.1$ & - & - & 68 \\
\hline
\end{tabular}

1. Except for LT2-03A, all of the peak ages are within $2 \sigma$ uncertainties of the $\chi^{2}$ ages which may represent the eruption ages.

2. Inherited age is the oldest grain age which failed the $\chi^{2}$ test. It indicates the minimum age of the former thermal events.

† The sample has been hydrothermally altered. The age represents the latest hydrothermal event rather than the eruption age.

$\ddagger$ This sample is a plutonic rock rather than volcanic rock. The date is the last thermal cvent record. The age represents the event of the later arc magmatism (see text discussion).

* Population method used; only pooled age calculated.

\# Data from Yang et al. (1992a). 


\section{Sediment contamination}

There is a consensus that the exposed parts of the Coastal Range of Taiwan were formed within the last $30 \mathrm{Ma}$ (Teng and Wang, 1981; Richard et al., 1986a; Teng, 1987; Lo, 1989), though it should be noted that some intrusive phases of the Coastal Batholith in eastern North Luzon have K-Ar ages of 40-50 Ma (Wolfe, 1981, 1988; Knittel and Defant, 1988). The present study revealed the existence of some inherited dates older than $39 \mathrm{Ma}$ (LT2-07, LT2-22). Possibly, these dates are not the residual magmatic records of the Coastal Range. One possible explanation is that the basement contains detrital sediments, which have been captured by magmatic eruptions. Since the cooling rate of the erupted material was very fast, the fission tracks of the detrital continent-derived zircons were not totally reset. Because they may have been already partially annealed, it is hard to estimate the age of such detrital sediments. The inherited dates ( $50 \mathrm{Ma}$ and $39 \mathrm{Ma}$ in Table 3) are the minimum ages of these detrital sediments.

There is other evidence suggesting sediment contamination of the volcanics in the northern part of the Taiwan-Luzon Arc, at least in the Bashi Segment, where the arc is colliding with the continent margin. C.-H Chen (1991, unpublished data) found some amorphous silica and slightly rounded phosphates (apatites) in the groundmass of biotite-bearing hornblende andesites of Lutao, which probably are the sediments derived from the continental crust. This observation provides direct evidence for sediment involvement at high crustal levels. The presence of unusually old, partially annealed FTD dates revealed by this study seems to support a process of sediment contamination in the upper crust when the magma rose toward the surface.

\section{Former igneous activity}

Volcanics in the studied area sometimes contain different kinds of xenoliths, including rock fragments of various kinds of andesites and cumulate nodules (Chen, 1986; Richard et al., 1986b; Jacques, 1987; Yang, 1992). These xenoliths are not only in chemical disequilibrium with their host rocks (Chen, 1989; Wang and Chun, 1990), but also have older radiometric ages than their host lavas. The degassing of phenocrysts in the high-temperature range may then result in anomalously old dates as determined by stepwise heating of the Ar-Ar method (Lo et al., 1994). Therefore, it is suggested that these xenoliths are the products of earlier magmatic activities, and were captured during later eruptive events.

In this study, we also have obtained some inherited ages ranging from $21 \mathrm{Ma}$ to $1.4 \mathrm{Ma}$. There are two possible explanations for these dates. They may either be the partially annealed dates of zircon-derived from continental sediments which have been subjected to more complete annealing, thus exhibiting younger dates than those in the range $50-39 \mathrm{Ma}$, or they simply date some older buried volcanics which may or may not have been influenced by annealing effects. On the basis of the very common occurrence of igneous xenoliths in chemical disequilibrium, we prefer the latter explanation.

\section{Comparison with other dating methods}

In Table 5 we compare our FTD results with age data obtained by other methods. It is not clear if our samples and those dated by other methods were collected from exactly the same body, but we are reasonably sure that they all are of the same rock types from the same area. Except for a few cases, the FTD ages are always younger than the others.

The $\mathrm{K}-\mathrm{Ar}$ ages span a wide range from $29.73 \mathrm{Ma}$ to $0.14 \mathrm{Ma}$ for the volcanic rocks. It is interesting that for corresponding samples of Lutao and Lanhsu the $\mathrm{K}-\mathrm{Ar}$ ages always fall between the eruption age and the inherited age derived by FTD. This implies that the $\mathrm{K}$-Ar dates could have been affected by the mixing with excess radiogenic argon inherited from xenocrystal hornblende and biotite which are derived from older volcanic/metamorphic rocks. This suggestion is further supported by the disagreement of $\mathrm{K}-\mathrm{Ar}$ ages determined on hornblendes and biotites separated from the same sample (LT2-20; in Table 5). So it can be generalized that the $\mathrm{K}$-Ar dates of Lutao and Lanhsu are always older than the eruption age determined by the FTD method. However, the FTD dates (CMG-10; CMG-15A) from Camiguin island (Philippines) are in agreement with the $\mathrm{K}-\mathrm{Ar}$ dates (Table 5). Moreover there are no inherited ages recorded in these samples (Table 4), that is, the pooled ages are the same as the $\chi^{2}$ ages. Samples LT2-35, LY5-10, LY5-20A also do not have partial annealing ages and the $K-A r$ ages are consistent with the $\chi^{2}$ ages of FTD within $2 \sigma$ error (Table 5). This implies that the $\mathrm{K}-\mathrm{Ar}$ ages are always consistent with the $\chi^{2}$ age of FTD where there is no evidence for the presence of partially annealed xenocrystic components.

The volcanics of Lanhsu have a wide range of $\mathrm{K}-\mathrm{Ar}$ ages $(25.9 \sim 2.32 \mathrm{Ma})$. The abnormal old age $(25.9 \mathrm{Ma})$ obviously results from the inherited high radiogenic argon in xenocrysts or potassium loss due to hydrothermal alteration (Richard et al., 1986a). Our FTD ages $(3.5 \sim 1.4 \mathrm{Ma})$ are much younger than the $\mathrm{K}-\mathrm{Ar}$ ages, although there are some older inherited ages $(21 \sim 3.6 \mathrm{Ma})$.

It should be noted that sample LT2-35 has concordant ages dated by FTD $(1.0 \pm 0.3 \mathrm{Ma}), \mathrm{Rb}-\mathrm{Sr}$ method $(1.1 \pm 0.2 \mathrm{Ma})$ and $\mathrm{K}-\mathrm{Ar}$ method $(1.31 \pm 0.10 \mathrm{Ma})$. It appears that LT2-35 is the only sample in our collection which might possibly have reached isotopic equilibrium in the Bashi Segment of the Taiwan-Luzon Arc, as indicated by a good $\mathrm{Rb}-\mathrm{Sr}$ isochron of plagioclase, hornblende and biotite (Lan et al., 1986).

Except for two samples (LY 5-01 and LY 5-04), the Ar-Ar dates are consistent with our FTD dates within $2 \sigma$ uncertainty. One possible explanation for the age differences between Ar-Ar and FTD ages is that we had collected the samples from different stages of eruption (especially hornblende andesite lavas which cover most of the central part of Lanhsu had a longer eruptive period).

\section{Magmatism in the Northern Part of the Taiwan-Luzon Arc}

\section{Taiwan Segment}

Although more than 20 samples of representative rock types were collected from the Coastal Range, only seven samples yielded zircons for FTD. The FTD age $(16 \pm 1 \mathrm{Ma})$ of CM-FT7 gives the minimum formation 
Table 5. Comparison between the age results $(\mathrm{Ma})$ of the different dating methods in North Luzon Arc volcanics

\begin{tabular}{|c|c|c|c|c|}
\hline Sample no. & $\begin{array}{l}\text { FTD age* } \\
(\mathrm{Ma} \pm 1 \sigma)\end{array}$ & $\begin{array}{c}\text { Rb-Sr age } \\
\text { (Lan et al., 1986) }\end{array}$ & $\begin{array}{c}\text { K-Ar age } \\
\text { (Juang, 1988) }\end{array}$ & $\begin{array}{c}\text { Ar-Ar age } \\
\text { (Lo et al., 1994) }\end{array}$ \\
\hline $\begin{array}{l}\text { CM-FT7 } \\
\text { CM-H1 }\end{array}$ & $\begin{array}{c}16 \pm 1 \# \\
8.3 \pm 0.6 \#\end{array}$ & - & $\begin{aligned} 14.2 & \pm 0.7^{\mathrm{e}} \\
9.0 & \sim 22.2^{\mathrm{c}}\end{aligned}$ & - \\
\hline WSP-2 & $3.3 \pm 0.6$ & - & - & $5.4 \pm 0.5$ \\
\hline LT2-02 & $1.5 \pm 0.2$ & - & - & $1.4 \pm 0.1$ \\
\hline LT2-13A & $0.80 \pm 0.17$ & $\frac{2.3 \pm 0.5^{\mathrm{a}}}{4.0^{\mathrm{b}}}$ & $\begin{array}{c}2.10 \pm 0.31^{\mathrm{c}} \\
2.41^{\mathrm{c}}\end{array}$ & 二 \\
\hline LT2-14 & $0.79 \pm 0.17$ & - & $\begin{array}{c}1.81 \pm 0.05^{\mathrm{d}} \\
2.94 \\
4.30 \pm 0.15^{\mathrm{d}}\end{array}$ & 一 \\
\hline LT2-15 & $0.93 \pm 0.16$ & - & $2.88^{\mathrm{c}}$ & - \\
\hline LT2-17 & $0.81 \pm 0.10$ & - & $\begin{array}{c}1.85 \pm 0.28^{\mathrm{d}} \\
1.88^{\mathrm{c}}\end{array}$ & - \\
\hline LT2-19D & $1.1 \pm 0.1$ & - & $2.05 \pm 0.30^{\circ}$ & - \\
\hline LT2-20 & $1.1 \pm 0.2$ & $\begin{array}{c}2.9 \pm 0.5^{\mathrm{a}} \\
3.4^{\mathrm{b}}\end{array}$ & $\begin{array}{c}1.62 \pm 0.08 \\
4.83\end{array}$ & $\overline{0.43^{\mathrm{e}}}$ \\
\hline LT2-22 & $1.7 \pm 0.3$ & - & $2.39 \pm 0.08^{c}$ & - \\
\hline LT2-31 & $0.99 \pm 0.14$ & - & $1.43 \pm 0.03^{c}$ & - \\
\hline LT2-32 & $0.54 \pm 0.11$ & $9.4 \pm 0.9^{\mathrm{a}}$ & $1.81 \pm 0.05^{d}$ & - \\
\hline LT2-35 & $1.0 \pm 0.3$ & $1.1 \pm 0.2^{\mathrm{a}}$ & $1.31 \pm 0.10^{c}$ & - \\
\hline LT2-38 & $1.2 \pm 0.1$ & - & 二 & $1.5 \pm 0.2$ \\
\hline LY5-01 & $1.8 \pm 0.3$ & - & $\begin{array}{c}9.10 \pm 2.50^{c} \\
14.8^{c} \\
25.9^{c}\end{array}$ & $6.6 \pm 0.1$ \\
\hline LY5-03 & $1.9 \pm 0.2$ & - & $11.2 \pm 1.2^{\mathrm{e}}$ & - \\
\hline LY5-04 & $2.4 \pm 0.2$ & - & $\begin{array}{l}4.58^{\mathrm{c}} \\
3.80^{\mathrm{c}}\end{array}$ & $3.5 \pm 0.1$ \\
\hline LY 5-07 & $1.4 \pm 0.4$ & - & $\begin{array}{l}5.45^{\mathrm{c}} \\
3.86^{\mathrm{c}}\end{array}$ & - \\
\hline LY5-08 & $1.5 \pm 0.2$ & - & $5.29 \pm 1.60^{\mathrm{c}}$ & - \\
\hline LY5-10 & $2.1 \pm 0.5$ & - & $2.43 \pm 0.09^{c}$ & - \\
\hline LY5-20A & $3.3 \pm 0.7$ & - & $2.32 \pm 0.14^{\mathrm{c}}$ & - \\
\hline SLY-01 & $0.04 \pm 0.01$ & $\begin{array}{c}1.0 \pm 1.0^{\mathrm{b}} \\
0.9 \pm 0.5^{\mathrm{u}} \\
0.3^{\mathrm{b}}\end{array}$ & $\begin{array}{l}1.19 \pm 0.05^{\mathrm{e}} \\
0.14+0.05^{\mathrm{d}}\end{array}$ & $0.5 \pm 0.1$ \\
\hline CMG-10 & $0.54 \pm 0.10$ & - & $2.80 \sim 0.40^{A}$ & - \\
\hline CMG-15A & $0.96 \pm 0.17$ & - & $2.80 \sim 0.40^{\mathrm{A}}$ & - \\
\hline NZ-08 & $26 \pm 1 \#$ & - & $26 \pm 2^{\mathrm{B}}$ & - \\
\hline
\end{tabular}

* $\chi^{2}$ age from Table 4 .

a. Plagioclase-biotite $\mathrm{Rb}-\mathrm{Sr}$ isochron age.

b. Amphibole-biotite Rb-Sr isochron age.

c. Whole rock $\mathrm{K}-\mathrm{Ar}$ age.

d. Biotite K-Ar age.

e. Hornblende $\mathrm{K}$-Ar age.

\# The last thermal event record.

A. Whole rock K-Ar age; data from Jacques (1987), Defant et al. (1990).

B. Whole rock K-Ar age of nearby basalt (NZ-03); data from Yang (1992).

age of the Chimei Igneous complex of the Coastal Range. This "age" is in agreement with the oldest plateau age determined by Ar-Ar method in northern Coastal Range (16.0 $\pm 0.2 \mathrm{Ma}$; Lo et al., 1994). The younger FTD ages of Wushihpi lavas $(3.3 \sim 2.2 \mathrm{Ma})$ may constrain the time of the arc-continent collision which stopped the magmatism in Coastal Range (Lo, $1989)$. The young "ages" $(1.5 \pm 0.1 \mathrm{Ma})$ obtained for the biotite-tuff from Tungho (TH-01; TH-02) may not represent later magmatic event in the Coastal Range, because it would post-date the collision and because biotite is rarely a phenocryst in the volcanics elsewhere in the Coastal Range. Lo and Song (1988) suggested that these tuffs were the eruption products from the nearest off-shore island, Lutao, about $40 \mathrm{~km}$ away, where strong eruptions of biotite-hornblende andesites oc- curred from $1.8 \mathrm{Ma}$ to $0.54 \mathrm{Ma}$ (Yang et al., 1992a). Thus, it appears that the volcanic activity of the Coastal Range commenced earlier than $16 \mathrm{Ma}$ and ceased about 2.2 Ma ago.

\section{Bashi Segment}

Based on the FTD ages, the distributions of eruptive products and possible eruption centers, Yang et al. (1992a) recognized at least five stages of major magma emission on Lutao from earlier than 2.0 ago to $0.54 \mathrm{Ma}$. The products of the earlier episodes were mainly basalts and basaltic andesites. During the later stages, however, the eruptive lavas were dominantly biotite-bearing hornblende andesites. It is worth noting that some of the "abnormal" lavas, which are highly enriched in LILE 
(e.g. Sr, Ba, Th, U) and LREE, were erupted during this period. Yang et al. (1992b) concluded that the enrichment of the magmas resulted from mixing with melts derived from low degrees of partial melting of the lower crust. They further suggested that crustal melting was induced by the severe collision event.

Our FTD eruption ages of Lanhsu volcanics are much younger than previous reported $\mathrm{K}-\mathrm{Ar}$ dates. On the basis of these FTD ages, occurrences, and distribution of different rock types, we have identified at least four volcanic stages in Lanhsu. Based on the inherited ages $(21 \sim 3.6 \mathrm{Ma})$ and the FTD age of rounded boulder (LY5-15B, 3.5 Ma; hornblende andesites), we can suggest that the magmatic activity started prior to 3.5 $\mathrm{Ma}$ ago, although there appears to be no outcrop of the products of this first stage. The exposed extensive eruptions began at about 3.3 Ma (LY5-20A). The products of second stage eruption are mainly volcanic breccias, pyroxene ( \pm hornblende) andesites, interbedded with tuffs, which are mainly distributed in the southern part of the island. Volcanism of the third stage appears to be limited to the central part of Lanhsu and the products are mainly hornblende andesite lava flows. The FTD ages of the lava flows (LY5-01, LY5-04) and volcanic neck (LY5-03) range from 2.4 to $1.8 \mathrm{Ma}$. The last volcanic stage occurred from 2.1 to $1.4 \mathrm{Ma}$. Its products are pyroxene-hornblende and hornblendepyroxene andesites. They are mainly distributed in the northern part of the island and occur as volcanic breccias interbedded with tuffs. Some of the lavas have been seriously altered by later hydrothermal activity. Based on our FTD ages for altered hornblende andesites (LY5-02; LY5-17), it can be suggested that hydrothermal activity existed in the island until $0.26 \mathrm{Ma}$.

Samples from Hsiaolanhsu have the youngest FTD ages $(0.04 \sim 0.02 \mathrm{Ma})$ among the samples studied. Its products are mainly biotite-hornblende andesites.

Based on the available radiometric ages, it could be suggested that the volcanic activity of the Batanes and Babuyanes islands of the Philippines occurred from 22.4 Ma to recent (Richard et al., 1986b; Jacques, 1987; Defant et al., 1989, 1990; Yang, 1992). Although only two FTD ages from Camiguin Island were obtained in this study $(0.96 \sim 0.54 \mathrm{Ma})$, they are consistent with the previously reported $\mathrm{K}-\mathrm{Ar}$ ages $(2.80 \sim 0.40 \mathrm{Ma})$. These results support the observation that the eastern volcanic islands always have younger eruption ages than the western ones (Jacques, 1987; Yang et al., 1995).

\section{North Luzon Segment}

The ages of northern Luzon basement can be constrained on the basis of the inherited ages of FTD obtained in this study. The age, about $70 \mathrm{Ma}$, is the minimum age of the basement. It might be older than that. Arc magmatism commenced at about $26 \mathrm{Ma}$ and continued to be active until late Miocene in the western part (Cordillera Central). However, a magmatic quiescent period of magmatism appears to have occurred from 20 to $2 \mathrm{Ma}$ in eastern Luzon (Sierra Madre) (Jacques, 1987). The magmatic activity was resumed at Mt Cagua during the Quaternary. This active volcano is believed to form the southward extension of the active volcanic chain of the Bashi Segment (Defant et al., 1989; Yang et al., 1995).

\section{Summary}

(1) The eruption ages of volcanics from the Northern part of the Taiwan-Luzon Arc (Taiwan and Bashi Segments) range from $6 \mathrm{Ma}$ to $0.02 \mathrm{Ma}$. The FTD ages can be used to constrain the formation age of Coastal Range (Taiwan Segment) from prior to $16 \mathrm{Ma}$ until the magmatism ceased about $2.2 \mathrm{Ma}$ ago due to arc-continent collision. Further southward, away from the point of the arc-continent collision, some volcanoes are still active. In this study, we obtained the youngest eruption age of $0.02 \mathrm{Ma}$ in Hsiaolanhsu, Taiwan.

(2) Based on the inherited ages, the partial annealing of fission-tracks in xenocrystic zircons is a common phenomenon in the igneous rocks of the Taiwan, and particularly the Bashi Segment. This is true especially for rocks near the place where the arc-continent collision occurs at present.

(3) On the basis of the very common occurrence of xenoliths, chemical disequilibrium and partial annealing phenomena of FTD, we conclude that high level crustal contamination was important within the vicinity of the collision zone between the Asian continent and the Taiwan-Luzon Arc.

(4) $\chi^{2}$ ages are better estimates of the eruption ages than pooled FTD ages. In most cases, the $\chi^{2}$ age is in good agreement with the peak ages of the composite probability density plot.

(5) Compared to the results of other radiometric dating methods for samples from the same area, FTD ages always have the youngest age among them. The $\mathrm{K}-\mathrm{Ar}$ ages are always consistent with the $\chi^{2}$ age of FTD where the sample contains no partial annealing records.

(6) The partial annealing of zircon populations in many samples record thermal activity which occurred prior to the eruptions of their host lavas. Based on the inherited ages, it is suggested that the basement of northern Luzon contains components which are older than $69 \mathrm{Ma}$.

Acknowledgements - The authors wish to thank Messrs. S. Shieh of Academia Sinica, Y. G. Chen, S. L. Chung, C. Y. Lee, W. S. Wang, S. H. Chung, S. Tsau of NTU and A. S. Daag of PHIVOLCS for their help in field work. TFY would like to thank Drs U. Knittel and M. D. Kurz for their continued encouragement during the preparation of this paper. B. $\mathbf{M}$. Jahn, S.-S. Sun and D. P. Kammer improved the manuscript and provided critical comments and valuable suggestions. Thanks are also due to Drs T. K. Liu, C. Y. Lan and C. H. Lo for their discussions. Dr M. T. Brandon providing the programs for the FTD age calculation is most appreciated. This paper was much improved by critical reviews by $U$. Knittel and Dave Coyle. This research was supported by National Science Council NSC 84-2111-M-002-030-GC, Central Geological Survey and Educational Ministry grants, Taiwan, ROC.

\section{REFERENCES}

Bal K. D., Lal N. and Nagpaul K. K. (1983) Zircon and sphene as fission track geochronometer and geothermometer: a reappraisal. Contrib. Mineral. Petro. 83, 199-203.

Brandon M. T. (1992) Decomposition of fission-track grain-age distributions. Am. J. Sci. 292, 535-564.

Brandon M. T. and Vance J. A. (1992) Fission-track ages of detrital zircon grains: implications for the tectonic evolution of the Cenozoic Olympic subduction complex. Am. J. Sci. 292, 565-636. 
Chen C.-H. (1986) Petrology and genesis of cognate plutonic inclusions in andesites of East Coastal Range, Lutao and Lanhsu, Taiwan. Memo. Geo. Soc. China 7, 259-281.

Chen C. H. (1989) Geochemical study of $\mathrm{Nd}-\mathrm{Sr}-\mathrm{O}$ isotopes of the Neogene island arc volcanics from Taiwan. Ph.D. dissertation, Institute of Geology, National Taiwan University, $198 \mathrm{pp}$. (in Chinese).

Chen C. H., Shieh Y.N., Lee T., Chen C.-H. and Mertzman S. A. (1990) $\mathrm{Nd}-\mathrm{Sr}-\mathrm{O}$ isotopic evidence for source contamination and an unusual mantle component under Luzon Arc. Geochim. Cosmochim. Acta 54, 2473-2483.

Defant M. J., Jacques D., deBoer J. and Joron J.-L. (1989) Geochemistry and tectonic setting of the Luzon arc, Philippines. Geol. Soc. Am. Bull. 101, 663-672.

Defant M. J., Maury R. C., Joron J.-L. Feigenson M. D., Leterrier J., Bellon H., Jacques D. and Richard M. (1990) The geochemistry and tectonic setting of the northern section of the Luzon Arc, the Philippines and Taiwan. Tectonophysics 183, 187-205.

Defant M. J., Maury R. C., Ripley E. M., Feigenson M. D. and Jacques D. (1991) An example of island-arc petrogenesis: geochemistry and petrology of the southern Luzon Arcs, Philippines. J. Petrol. 32, 455-500.

Fleisher R. L., Price P. B. and Walker R. M. (1975) Nuclear Tracks in Solids, Principles and Applications, University of California Press, Berkeley, 605 pp.

Galbraith R. F. (1988) Graphical display of estimates having differing standard errors. Technometrics 30, 271-281.

Galbraith R. F. (1990) The radial plot: graphical assessment of spread in age. Nucl. Tracks Radiat. Meas. 17, 207-214.

Galbraith R. F. and Green P. F. (1990) Estimating the component ages in a finite mixture. Nucl. Tracks Radiat. Meas. 17, 197-206.

Gleadow A. J. W. and Brooks C. K. (1979) Fission track dating, thermal histories and tectonics of igneous intrusions in east Greenland. Contrib. Mineral. Petrol. 71, 45-60.

Green P. F. (1981) A new look at statistics in fission-track dating. Nucl. Tracks 5, 77-86.

Green P. F. (1985) Comparison of zeta calibration baselines for fission-track dating of apatite, zircon and sphene. Chem. Geol. 58, $1-22$.

Haack U. (1977) The closing temperature for fission track retentions in minerals. Am. J. Sci. 277, 459-464.

Hurford A. J. (1990) Standardization of fission track dating calibration: recommendation by the Fission Track Working Group of the I.U.G.S. Subcommission on Geochronology. Chem. Geol. 80, $171-178$.

Hurford A. J. and Green P. F. (1982) A users' guide to fission track dating calibration. Earth Planet. Sci. Lett. 59, 343-354.

Hurford A., Fitch F. J. and Clarke A. (1984) Resolution of the age structure of the detrital zircon populations of two Lower Cretaceous sandstones from the Weald of England by fission track dating. Geol. Mag. 121, 269-277.

Juang W. S. (1988) Geochronology and chemical variations of late Cenozoic volcanic rocks in Taiwan. Ph.D. dissertation, Institute of Oceanography, National Taiwan University, $231 \mathrm{pp}$. (in Chinese).

Juang W. S. and Chen J. C. (1990) Geochronology and chemical variations of volcanic rocks along the arc-continent collision zone in eastern Taiwan. Bull. Natn. Museum Natural Sci. 2, 89-118.

Jacques D. (1987) Geologie et petrologie de l'archipel Babuyan et des Monte Tabungon et Cagua Nord Luzon, Philippines: implications magnatologigues geodynamiques (These de Doctoral). Brest, Frande, Universite de Bretagne Occidentale, 245 pp.

Knittel U. and Defant M. J. (1988) $\mathrm{Sr}$ isotopic and trace element variations in Oligocene to recent igneous rocks from the Philippine island arc: evidence for recent enrichment in the sub-Philippine mantle. Earth Planet. Sci. Lett. 87, 87-99.

Knittel U., Defant M. J. and Raczek I. (1988) Recent enrichment in the source region of are magmas from Luzon island, Philippines: $\mathrm{Sr}$ and $\mathrm{Nd}$ isotopic evidence. Geology 16, 73-76.

Knittel U., Trudu A. G., Winter W., Yang T. F. and Gray C. M. (1994) Volcanism above a subducted extinct spreading center: a reconnais- sance study of the North Luzon Segment of the Taiwan-Luzon Volcanic Arc (Philippines). J. SE Asian Earth Sci. 11, xxx-xxx.

Kowallis B. J., Heaton J. S. and Bringhurst K. (1986) Fission-track dating of volcanically derived sedimentary rocks. Geology 14, 19-22.

Krishnaswami S., Lai D. and Prabhu N. (1974) Characteristics of fission track in zircon: applications to geochronology and cosmology. Earth Planet. Sci. Lett. 22, 51-59.

Lan C. Y., Shen J. J. S. and Lee T. (1986) A Rb-Sr isotopic study of andesites from Lutao, Lanhsu, and Hsiao-Lanhsu, eruption ages and isotopic heterogeneity. Bull. Inst. Earth Sci. 6, 211-226.

Liu T. K. (1982) Tectonic implication of fission track ages from the Central Range, Taiwan. Proc. Geol. Soc. China 25, 22-37.

Liu T. K. (1988) Fission track dating of the Hsuehshan Ranges: thermal record due to arc-continent collision in Taiwan. Acta Geol. Taiwan. 26, 279-290.

Lo C. H., Onstott T. C., Chen C. H. and Lee T. (1994) An assessment of $40 \mathrm{Ar} / 39 \mathrm{Ar}$ dating for the whole-rock volcanic samples from the Luzon Arc near Taiwan. Chemical Geology. 114, 157-178.

Lo H. J. (1989) Evolution of the volcanic arcs of the Coastal Range, eastern Taiwan. Acta Geol. Taiwan. 27, 1-18.

Lo H. J. and Song S. R. (1988) Records of Pliocene to Pleistocene volcanic activities of the Coastal Range of eastern Taiwan. Abstract for Annual Meeting of Geological Society of China, held in Taipei, Taiwan.

McDermott F., Defant M. J., Hawkesworth C. J., Maury R. C. and Joron J. L. (1993) Isotope and trace element evidence for three component mixing in the genesis of the North Luzon arc lavas (Philippines). Contrib. Mineral Petrol. 113, 9-23.

Richard M., Bellon H., Maury R. C., Barrier E. and Juang W. S. (1986a) Miocene to recent calc-alkalic volcanism in eastern Taiwan: K-Ar ages and petrography. Memo. Geo. Soc. China 7, 369-382.

Richard M., Maury R. C., Bellon H., Stephan J. F., Boirat J. M. and Calderon A. (1986b) Geology of Mt. Iraya volcano and Batan island, northern Philippines. Philippine J. Volcanology 3, 1-27.

Sharma Y. P., Lal N., Bal K. D., Parshad R. and Nagpaul K. K. (1980) Closing temperatures of different fission tracks clocks. Contrib. Mineral. Petro. 72, 235-336.

Shieh S. L. (1990) Fission-track dating of zircons from several east-west cross sections Taiwan island. MS. thesis, Institute of Geology, National Taiwan University, 134 pp. (in Chinese).

Steven T. A., Mehnert H. H. and Obradovish J. D. (1967) Age of volcanic activity in the San Juan Mountains, Colorado. U.S. Geol. Survey Prof. Paper 575-D, D47-D55.

Tagami T., Lal N., Sorkhabi R. B., Ito H. and Nishimura S. (1988) Fission track dating using external detector method: a laboratory procedure. Mem. Faculty Sci. Kyoto Univ. Ser. Geol. Mineral LIII, 1-30.

Teng L. S. (1987) Tectonostratigraphic facies and geologic evolution of the Coastal Range, eastern Taiwan. Mem. Geol. Soc. China 8, 229-250.

Teng L. S. (1990) Geotectonic evolution of late Cenozoic arc-continent collision in Taiwan. Tectonophysics 183, 57-76.

Teng L. S., Chen W. S., Wang Y., Song S. R. and Lo H. J. (1988) Toward a comprehensive stratigraphic system of the Coastal Range, eastern Taiwan. Act Geol. Taiwan. 26, 19-35.

Teng L. S. and Wang Y. (1981) Island arc system of the Coastal Range, eastern Taiwan. Proc. Geol. Soc. China 24, 99-112.

Wagner G. A. (1979) Correction and interpretation of fission tracks. In Lectures in lsotope Geology (edited by Jager E. and Hunziker J. C.), Springer Veriag, New York, pp. 170-177.

Wagner G. A. (1988) Apatite fission-track geochrono-thermometer to $60^{\circ} \mathrm{C}$ : projected length studies. Chem. Geol. 72, 145-153.

Wagner G. A. and Storzer K. (1972) Fission track length reductions in minerals and history of rocks. Trans. Amer. Nucl. Soc. 15, 127pp.

Wang W. S. and Chen C.-H. (1990) The volcanology and fission track age dating of pyroclastic deposits in Tatun Volcano group, northern Taiwan. Acta Geol. Taiwan 28, 1-30.

Wang $Y$. and Chung S. H. (1990) A preliminary mineralogical study of the Lutao andesites. Spec. Publ. Central Geol. Survey 5, $77-91$. 
Wolfe J. A. (1981) Philippine geochronology. J. Geol. Soc. Philip. 35, 1-29.

Wolfe J. A. (1988) Arc magmatism and mineralization in North Luzon and its relationship to subduction at the East Luzon and North Manila trenches. J. SE Asian Earth Sci. 2, 79-93.

Yang T.-Y. (1987) Petrochemical and fission-track studies of the Chimei Igneous Complex of the Coastal Range, eastern Taiwan. MS thesis, Institute of Geology, National Taiwan University, 123 pp. (in Chinese).

Yang T.-Y. (1992) Magma evolution of North Luzon Arc and the tectonic implication. Ph.D. dissertation, Institute of Geology, National Taiwan University, 458 pp. (in Chinese).

Yang T.-Y., Liu T. K. and Chen C.-H. (1988) Thermal event records of the Chimei Igneous Complex: constraint of the ages of magma activities and the structural implication based on fission-track dating. Acta Geol. Taiwan 26, 237-246.

Yang T.-Y., Chen C.-H. and Lee T. (1992a) Fission-track dating of Lutao volcanics: implications of partial annealing and eruption history. J. Geol. Soc. China 35, 19-34.

Yang T.-Y., Lee T. and Chen C.-H. (1992b) Petrogenesis of Lutao volcanics, Taiwan: evidences of multiple source components for North Luzon Arc. Abstract for the 29th IGC meeting, Kyoto.

Yang T. F., Lee T., Chen C.-H., Cheng S. N., Knittel U., Punongbayan R. S. and Rasdas A. R. (1995) A double island arc between Taiwan and Luzan: tectonic manifestation of ridge subduction. Tectonophysics. (Accepted).

Zaun P. E. and Wagner G. A. (1985) Fission-track stability in zircons under geological conditions. Nucl. Tracks 10(3), 303-307. 